Vol. 8, No. 1, 2021

https://doi.org/10.23939/eem2021.01.014

UDC 657.1.012.1:336.74

JEL Classification Code: M41, 033

\author{
O. Skasko \\ Lviv Polytechnic National University, Ukraine, Doctor, Professor \\ E-mail: Oleh.I.Skasko@lpnu.ua, \\ ORCID ID: 0000-0002-7746-0801
}

I. Manchur

Lviv Polytechnic National University, Ukraine, Postgraduate

E-mail: Iryna.M.Manchur@lpnu.ua

ORCID ID: 0000-0002-8921-9142

\title{
THEORETICAL FUNDAMENTALS OF ACCOUNTING AND REPORTING INFORMATION CONSTRUCTION IN THE DIGITAL ECONOMY ENVIRONMENT
}

\begin{abstract}
Annotation. Modern theoretical and applied principles of digitalization and its impact on the information security of enterprises are revealed. The main digital trends that determine the directions of development of accounting and financial reporting. Peculiarities of the Ukrainian economic environment and possibilities of introduction of the means of informatization developed in the world theory are analyzed. The mechanisms of large-format automation of financial reporting processes and the use of document flow in the activities of Ukrainian enterprises are studied. The hypothesis of this study is the assumption of the positive impact of digital technologies in the reporting of socially significant Ukrainian enterprises. The study used general and specific research methods, namely: the method of systematic analysis of domestic and foreign experience in the digital economy to justify a systematic approach to the study of phenomena and processes of building a new paradigm of interaction of economic agents; dialectical method for studying the genesis of the digital economy as a defining trend of modern global socioeconomic development; method of induction to determine the factors influencing the environment of digitization of accounting information; the grouping method provided systematization of factors influencing the development of digitization processes, etc. It is substantiated that digitalization as an environment for economic processes and operations will lead to changes in methodological tools of accounting and virtualization of accounting processes.
\end{abstract}

Key words: digital economy, digitalization of financial statements, QR-code, automation, electronic document management, accounting.

\section{Introduction}

Objective changes in the growing role of information and information technology as factors of public life have led to the transition to the information society and the formation of the digital economy as a defining trend of global socioeconomic development. Its latest post-industrial stage is characterized by constant technological innovations, increasing informatization of social and economic relations, increasing employment in IT, production of information products and services and increasing their share in gross product, use of computer networks and global information space for effective communication, access to global information resources and meeting the needs for information products and services, etc.

Digitalization is a prerequisite for global social transformations that determine the trajectory of modern business, provides unprecedented opportunities to create value based on its virtualization. Increasingly, the strategic plans of countries mention the need to build a digital society, the development of the digital economy, which is characterized by the virtualization of all 
socio-economic, educational, social and political processes.

The challenges posed by the globalized economic environment to the strategies of modern companies, necessitate their involvement in the processes of digitalization of society, which is manifested in a change in the paradigm of interaction of economic agents. The leaders of globalization processes are international companies that are actively implementing digital technologies in business processes. Digitalization of business processes permeates all existing communication relationships between business entities and stakeholders. It creates a new virtual environment for them, offering new forms of information relations between them. At the same time, it transforms the organizational and methodological principles of the accounting system as an information system of the company, which determines the relevance of the subject of this study.

\section{Research analysis and problem statement}

Problems of introduction of digital technologies in the sphere of Ukrainian economy are covered in works of domestic scientists and researchers [1-11]. In particular, the study of one group of scientists, among which we note Lavrynenko A. A. and Shulga O. M. substantiate the development of modern information technologies in the economy as a systemic element of digitalization [1].

Another group of scientists, in particular, Novikova O. F. and Ostafiychuk Ya. V., Rudenko M. V. emphasize that the key to transformations in the social and labor sphere will be the digitalization of society $[2 ; 3]$. Scientists Kraus N. M., Kraus K. M., Goloborodko O. P. in their works they summarize the characteristic special trends of the digital economy and argue that the digital age is changing the approach to doing business [4]. Another group of scientists, including Guley A. I., Guley S. A., Yazlyuk B. O. synthesize the main approaches to the formation of a new digital era on the border of real and virtual socioeconomic space of interaction [5]. In general, summarizing their work, it can be noted that their works consider the general principles of digital processes in the economic and social development of Ukraine.

Paying tribute to these scientists, we note that the construction of accounting information they paid insufficient attention. In our opinion, it is the field of accounting that will undergo the largest changes in the direction of digitalization of accounting, analytical and control processes, which emphasizes the importance of research at the present stage of this sector of the economy.

To study these issues, we also studied the approaches of foreign scholars and practitioners on public perception and the importance of electronic services for the development of civil society and improving the socio-economic living conditions of the population. Thus, these issues were investigated in their works: the prerequisites for the transformation of organizational and methodological principles of the accounting system were studied by P. Dunleavy [6], H. Margetts,G. Jansson [7], M. Gustafsson, G. Goldkuhl.

Summarizing their research, it can be argued that their work focuses on the priority of changes in the processes of formation of accounting information. Given the importance of the further evolution of accounting science, it is appropriate to study the further development of accounting methodology and financial reporting on the basis of deepening its digitization and compliance with user requests.

The purpose of the article is to reveal the theoretical foundations of the construction of accounting information in the digital economy and highlight the prospects of a new accounting paradigm.

The methodological basis is the application in the process of scientific research of the historical method of cognition and general scientific principles, which include empirical (observation, comparison, description) and general logical (analysis, synthesis, generalization, induction, deduction, analogy, system approach) methods.

\section{Research results}

The concept of "digitization" is relevant and new for both practitioners and theorists of economics, in particular the science of accounting. In this regard, there is sometimes a substitution of concepts that are often mistaken for synonyms "informatization" and "digitalization". And if the first of them has long been common in the theory and practice of accounting, the second was introduced into scientific interpretation relatively recently. In particular, informatization does not modify the principles of interaction between economic agents, 


\section{O. Skasko, I. Manchur}

but only creates additional channels for data dissemination, duplicating (and sometimes simply reproducing) its analog form in digital form. In addition, changing the format of data generation and transmission in the computerized accounting system creates only a number of other, other than paper, means of information interaction of economic agents. However, the digitalization of the accounting system defines a new concept of data generation and use, allows you to digitize and parameterize a number of objects that are not classically objects of accounting. Therefore, qualitatively new databases on business processes of the enterprise contribute to the formation of prognostic functions of the accounting system that can be used by all subsystems of enterprise management.

Accounting is part of a general information system that converts the primary data recorded in documents into a management product. Such a product is processed information that has the properties of the product. From this point of view, accounting is a means of producing a special kind of information - information that has value, cost, price and other categories of commodity production [5]. In a digital economy, accounting, while maintaining its relevance and demand for the product created, should become a clear component of the system of obtaining, processing and transmission of economic information. Otherwise, it is subject to a significant risk of "dissolving" in modern electronic information systems, which are dynamically evolving and expanding the scope of its application [8].

In this regard, there is a need to introduce electronic document management (hereinafter EDI), which is based on an electronic document. Digitization in accounting is impossible without EDI, the advantage of which is accelerated cash flow and resource savings. Documentation in accounting is a way of primary registration of information.

The final generalizing stage is the formation of reporting. Therefore on the basis of primary electronic documents the document of the highest level - the electronic reporting is formed, and as Minkovskaya AA notes "The final product of accounting goes to a fundamentally new and higher level, which significantly expands the range of its" consumers "- internal and external users of information". According to the author, "integrated reporting is also based on the digitization of documents and reporting, as the submission of reports in paper form is devoid of systematic perception" [9].

An important achievement of the digital economy is the use of contactless information identification technology, namely biometric, card technology, radio identification, machine vision, speech data entry, it is necessary to separate QRcodes and devices for their reading. QR codes are a convenient, simple and interactive way to receive and disseminate information. The advantage of this code is that a large amount of information can be encoded and can be quickly accessed by recognition and scanning by digital devices. The term "QR-code" is an abbreviation of the English "Quick Response code" - (quick response code). For the first time these graphic codes were researched and applied in Japan. They are used to transfer information from media to device and can contain information such as phone numbers, reminders, text messages, product descriptions, and more. The code can be used on packaging, bulletin boards, storefronts and to track products, goods and identify objects.

The advantages and disadvantages of QRcodes are described in Table 1.

\section{The advantages and disadvantages of QR-codes}

\begin{tabular}{|l|l|}
\hline \multicolumn{1}{|c|}{ The advantages of QR-codes } & \multicolumn{1}{|c|}{ The disadvantages of QR-codes } \\
\hline $\begin{array}{l}\text { storage of large amounts of digital and textual information } \\
\text { in any language }\end{array}$ & $\begin{array}{l}\text { low public understanding of new QR-coding } \\
\text { technologies (low coverage of the target audience) }\end{array}$ \\
\hline $\begin{array}{l}\text { the printing size of the code can be quite small and at the } \\
\text { same time it is characterized by high recognition speed }\end{array}$ & $\begin{array}{l}\text { technical shortcomings (for example, incorrectly } \\
\text { installed device on the phone) }\end{array}$ \\
\hline ability to read in any direction (omnidirectional or $360^{\circ}$ scan) & - \\
\hline $\begin{array}{l}\text { almost any surface is suitable for placement, which is also } \\
\text { very important }\end{array}$ & - \\
\hline $\begin{array}{l}\text { damage resistance, even if part of the code is damaged (to } \\
30 \%), \text { it can still be read }\end{array}$ & - \\
\hline
\end{tabular}


An important area of control, analytical and accounting work of the company is to report about the status and availability of non-current assets, as tangible assets are interrelated with investments. The unfitness and loss of assets can lead to a loss of income, and the need to restore them or replace them with new investments.

Collecting data on the availability, condition and complete information about objects is quite a laborious process, especially for large enterprises. Usually this procedure is carried out by different departments within the given powers, so it partially complicates the process of generalization of data obtained from different sources. To simplify the above data collection system, which is typical for many companies, it is possible to use QR-coding of objects with a special code for a particular enterprise at each object. Of course, for the QRcoding system you need to order a large number of codes and have special equipment, in particular, mobile devices (smartphones, tablets), as well as appropriate software for direct use, but after the introduction of this system it is possible to quickly collect data. responsible persons will be able to have access to data on objects that previously belonged to the competence of another unit. All data that will be provided to management will be displayed in one database, which is created by the unit, which will facilitate rapid decision-making.

During the inventory, the use of QR-codes will speed up the process of verifying existing noncurrent assets, because in QR-codes all data about these objects are encrypted. When reading the code, information about a specific object is revealed, which is indicated in the inventory card of the noncurrent asset. In the QR code, the image of the object can be encoded and updated during the next inventory. The image of the object provides an opportunity to assess the status and replace the asset between the periods of inventory. In case of introduction of QR-coding the process of work of the inventory commission will be simplified that will lead to acceleration of data aggregation and will allow to make the decision quickly.

Mobile inventory management with QR codes means that employees will be able to record transactions, even if they are at remote sites. Record operations at the very moment when they are performed, by scanning the QR code with a mobile device. This reduces the likelihood of wasting exactly what is needed to upgrade equipment in a timely manner, as well as helping to reduce lost inventory and non-current assets and avoid accounting and reporting errors. To create an effective asset tracking and inventory system using $\mathrm{QR}$ codes and smartphones, you need quality software and applications to work.

Asset management with tracking software and QR code inventory tags will help prevent loss and damage to the company's equipment, upgrade equipment in a timely manner, and reduce repair costs. In addition, saving time compared to manually performing the required reconciliation of assets will save a lot of hours of work for employees who may be devoted to other activities. And although such an innovation requires an initial investment of time and money, but it is justified and appropriate, as it will have a positive impact on the level of organization of accounting work of the enterprise, improving the efficiency of accounting staff [11, p. 320].

For the institute of accounting, a clear manifestation today is the use in practice of the software package "Technological Revolution 4.0", which fully automates production, in which the management of all processes is carried out in real time and taking into account changing external conditions. Digital, electronic or IT-oriented structured version of financial reporting promotes accounting and ensures its development in accordance with the latest technologies of transmission and provision of information on the one hand and the growing volume, complexity and importance of financial information on the other.

Digital financial reporting is financial reporting using a structured computer-based form as opposed to the traditional paper financial reporting format, electronic versions of paper reports such as HTML, PDF, or as a readable text editor document. only by man [13].

Systems based on the XBRL standard (eXtensible Business Reporting Markup Language) are widespread in the world and are standardized representations of electronic business information selected by Ukraine. The advantages of using this system for the formation of financial statements are automaticity and speed, as well as consolidated reporting. The advantages of the system are also 


\section{O. Skasko, I. Manchur}

the simplification of searching for financial reporting data on the Internet, data processing and analysis, more efficient regulatory process. The XBRL format is convenient for submitting mandatory reporting to regulatory authorities and for downloading reports on the websites of organizations.

The "taxonomy", which is expressed as a list of items and indicators of financial statements and its elements to be disclosed, as well as the relationships between them and other elements of the taxonomy, is also important for the construction of the new system. Pursuant to Article 1 of the Law of Ukraine "On Accounting and Financial Reporting in Ukraine", the Ministry of Finance of Ukraine adopted an order dated 07.12.2018 No. 983 "On approval of translation of taxonomy of financial statements according to international financial reporting standards", which comprehensively implements the approach to digitization of financial statements.

Digital financial reporting is recognized by both humans and machine processes. The essence is in the appropriate use of intelligent technologies and computer technology for the contextual content of financial statements, which has traditionally been considered the most complex, time-consuming and responsible area of work of a professional accountant. Digital financial reporting, available to its users through the electronic distribution of modern means of communication and the global electronic network the Internet at any time, anywhere. Such information does not require decoding, and regulators, financial and government agencies, business systems receive the same understanding of financial facts and the relationships between registered facts. The machine's perception of a digital financial report is ensured by the structured nature of the information presented in the electronic financial report, metadata explaining the business rules associated with the creation of a computerized financial report, and metadata that helps other users of financial statements, such as investors and analysts who use financial reporting information interact with these machine-readable documents to efficiently and successfully exchange values between businesses and processes.
Knowledge of the mechanism of the financial report and how to create a financial report is carefully expressed by people in a machinereadable form. This does not mean that all knowledge can be expressed; first of all, only objective knowledge that makes a computer program capable of reproducing the formalization of logical and mathematical operations described by a person. Subjective knowledge, such as the judgment of a professional accountant, can never be expressed in terms that are understandable to the technician.

Automation of financial statements can be achieved to the extent that data and metadata, as well as software algorithms allow. The advantage of digital financial reporting is the transfer to computer technology of routine mechanical tasks related to the preparation of financial statements. We are not talking about all tasks, but only those that can be effectively achieved through technology. This, in turn, changes the nature of the professional activity of an accountant, who is given an active role, which involves the possession of expert and consulting skills, requires high competence of the manager associated with the creation and verification of financial statements.

According to research by Spilnyk I., Palyukh M. "digital financial reporting frees both professional accountants who create these reports and financial analysts and regulators who use information from these reports from such tasks as assessing the quality of information on the merits and providing formal objective aspects, such as logical and mathematical consistency of the report, which will allow professional accountants and users to focus on professional judgments and other subjective aspects that can not be automated" [16, p. 117].

\section{Research results}

Thus, the operation of international enterprises in different countries, the volume of their market coverage, etc. require the computerization of tasks performed by people. This will also reduce the labor costs associated with the preparation of financial statements, eliminate human error, improve quality and reduce the risk of non-compliance, reduce the time to prepare financial report. It is expected that the digital reporting system will eliminate duplication when submitting information to different authorities for identical or similar forms of reporting, depending 
Theoretical fundamentals of accounting and reporting information construction...

on the requirements of regulators or regulatory authorities, as it provides for a single window for electronic reporting, which will be accessible to all supervisors. enterprise.

\section{References}

1. Lavrenenko V. V., Shulha O. M. (2018). Development of modern information technologies in the economy as a system element of digitalization. Ekonomika ta pidpryiemnytstvo. [Economics and entrepreneurship], 40, 26-33 [in Ukrainian].

2. Novikova O. F., Ostafiichuk Ya. V. (2018). Digitalization of society and sustainable development is the key to transformations in the social and labor sphere. Tsyfrova ekonomika. [Digital economy], 277-282 [in Ukrainian].

3. Rudenko M. V. Digitization of the economy: new opportunities and prospects. Economy and state. Ekonomika ta derzhava [Economy and state], 11, 61-65. [in Ukrainian].

4. Kraus N. M., Holoborodko O. P., Kraus K. M. (2018). Digital economy: trends and prospects of avant-garde development. Efektyvna ekonomika: [Efficient economy], [in Ukrainian].

5. Kulynych M. B. (2011). Assessment of the efficiency of accounting and analytical support of revenues and expenses. Ekonomichni nauky [Economic sciences], 4,53-54 [in Ukrainian].

6. Margetts H. (2002). Better Public Services through e-government: Academic Article in support of Better Public Services through e-government / H.Margetts, P.Dunleavy.

7. Lindgren I.(2013). Electronic services in the public sector: a conceptual framework / I. Lindgren, G. Jansson // Government Information Quarterly. 2013. Vol. 30, No. 2. P. 163-172.

8. Odyntsova T. M., Rura O. V. (2018). Development of types, objects and methods of accounting in the digital economy and information society. Ekonomichni nauky[Economic sciences], 4, 120131. [in Ukrainian].

9. Mynkovskaia A. A.(2018). Digitalization of accounting and reporting, and the possibility of its development in the Republic of Belarus. Fizyko-matematychna osvita. [Physical and mathematical education], 4(18), 112-114. [in Ukrainian].

10. Dibrova T. H., Tsukanova I. V.(2013). The features of use qr-code in the integrated marketing communications. Marketynh [Marketing], 10, 429434 [in Ukrainian].

11. Radivilova H., Spilnyk I.(2018). QR-coding in accounting and asset management: the benefits and prospects of use. Tsyfrova ekonomika: trendy ta perspektyvy : materialy Mizhnarodnoi naukovopraktychnoi konferentsii [Digital economy: trends and prospects: materials of the International scientific-practical conference] (p. 319-320. October 25, 2018, Ternopil, Ukraine [in Ukrainian].

12. Managing Fixed Assets Using QR Codes and a Smartphone.

13. Ivakhnenkov S. V. (2008). Electronic reporting technologies as a prerequisite for analysis and control of financial statements. Oblik $i$ finansy APK: bukhhalterskyi portal [Accounting and finance of agro-industrial complex: accounting portal], 4 Retrieved from http://magazine.faaf.org.ual elektronnitehnologii-zvituvannya-yak-peredumovaanalizu-ta-kontrolyu-finansovoi-zvitnosti.htm [in Ukrainian].

14. Minfin planuie zatverdyty taksonomiiu finzvitnosti 2018. [The Ministry of Finance plans to approve the taxonomy of financial statements in 2018] (2018) Retrieved from https://news.dtkt.ua/ accounting/reposts/50602 [in Ukrainian].

15. Tsyfrova finansova zvitnist [Digital Financial Reporting] Retrieved from https://en.wikibooks. org/wiki/Digital_Financial_Reporting. [in Ukrainian].

16. Spilnyk I., Paliukh M (2018). Digital format of financial reporting: essence, advantages, prospects. Digital economy: trends and prospects. Tsyfrova ekonomika: trendy ta perspektyvy : materialy Mizhnarodnoi naukovopraktychnoi konferentsii [Digital economy: trends and prospects: materials of the International scientific-practical conference] (p. 115-117. October 25, 2018, Ternopil, Ukraine [in Ukrainian]. 